\title{
A STUDY ON THE MEDICINAL CHEMISTRY OF CURCUMA LONGA
}

\author{
Thaneshwar Subedi \\ Department of Chemistry, Prithvi Narayan Campus, Tribhuvan University, Pokhara \\ For correspondence: thaneshworsubedi@gmail.com
}

\begin{abstract}
Plants are the major source of drug in the modern as well as traditional system of medicine throughout the world. Curcuma longa belonging to the family Zingiberaceae, is a medicinally important perennial herb distributed throughout the tropical and subtropical regions of the world from sea level to $1200 \mathrm{~m}$. Therapeutically, C. longa has been used for curing various diseases such as asthma, anemia, chronic bronchitis, fever, dysentery, cough, diabetes, diarrhea, eye disease, hepatitis, hysteria, indigestion, itching, leprosy, liver disorder, menstrual disorder, peptic ulcer, small pox, chicken pox, tonsillitis, urinary infection etc. The objective of the study was phytochemical screening of $C$. longa for highlighting the traditional uses and pharmacological properties of its rhizomes. The rhizomes were collected from Pokhara Metropolitan -3, Nadipur, Nepal in November 2019. The collected rhizomes were washed thoroughly, cut into pieces, shaded dried completely, grinded into fine powder, extracted by Soxhlet extractor, evaporated the extract to get dark orange residue. Phytochemical screening was conducted by using standard methods. Phytochemical analysis of methanolic and ethanolic rhizome extract of C. longa showed that it contained alkaloids, steroids, tannins, flavonoids, carbohydrates, cardiaic, glycosides, phytosterol, anthocyanin, emodins, diterpenes, leuco anthocyanin, anthroquinone, chalcones, phenols, coumarin and phlobatannin in methanolic extract but not in ethanolic. Previous pharmacological studies on C. longa showed that it possessed antiviral, antifungal, anticancer, antidepresent, antimalarial, antimicrobial, antioxidant, antiplatelet, antibacterial, antivenum, antimutagenic and anticarcenogenic activities. Further phytochemical analysis using solvents of different polarity is necessary to identify much more phytochemical constituents for highlighting pharmacological and traditional medicinal properties.
\end{abstract}

Key words: Curcuma, medicinal chemistry, phytochemistry, traditional medicine

\section{INTRODUCTION}

Medicinal plants contain compounds or synthesize metabolites that can be used for producing useful drugs (WHO, 2002). The world health organization estimated that $80 \%$ of people worldwide rely on herbal medicines partially for their primary health care (IUCN, 2011). Plants are the major source of drug in the modern as well as traditional system of medicine throughout the world. Over $60 \%$ of all pharmaceuticals are plant based (Jain etal., 2007). Curcuma longa commonly known as turmeric (Haledo in Nepali and Haldi in Hindi) belongs to the family Zingiberaceae. It is extensively cultivated for its rhizomes. It is a perennial herb distributed throughout tropical and sub-tropical regions of the world including India, Pakistan, Bangladesh, Sri Lanka and Nepal. Nepal is rich in culture and biodiversity, therefore, different traditional systems of medicine have been in 
practice. Turmeric has been used in Nepal and India as a drug in Ayurvedic and Unani system of medicine from the time immemorial to treat wide range of ailments.

Curcuma longa is cultivated from sea level up to $1200 \mathrm{~m}$ at temperature $20-30^{\circ} \mathrm{C}$ with good rain fall, warm and humid climate. Turmeric cultivated in the hill is reported to be of a better quality than that raised in the plans. The light green leaves of the plant are large (up to $1.2 \mathrm{~m}$ long and 8-12 $\mathrm{cm}$ wide) oblong, narrowed to the base (Hooker, 1990). The individual flowers are yellowish white or yellow in colour. The fruit is globular capsule (Thomas, 2000), but it is rare (Anonymous, 2004). The rhizomes are fleshy, branched with bright orange to yellow (Ross, 2001). The primary rhizomes are ovate or pearshaped are known as 'bulb' or 'round' turmeric while secondary rhizomes are more cylindrical which are known as 'fingers' and contain more yellow colouring matter than the bulb variety (Evan, 2002). Curcuma longa has an aromatic odour and a warm somewhat bitter taste. It is commonly used as a preservative, food additive, and food colouring agent. Large quantities of turmeric are used in the preparation of curries and sauces. It forms an integral component of diet (Ahmad et al., 2010). In addition to its use as spices and pigments, turmeric has been used in Nepal and other Asian countries for medical purposes for centuries.

Traditionally, C. longa has been used as aromatic stimulant, tonic, blood purifier, antiparasitic, in sprains, wounds, injuries, chest and abdominal distension, muscous discharge, conjuctivities etc (IUCN, 2000). Its rhizome is traditionally, used as blood purifiers, tonic to brain and heart, to treat leucoderma, piles, bronchitis, asthma, tumours, tuberculosis, glands on the neck, enlargement of spleen, to check leucorrhal and gonorrhoea discharge It is used as preservative, colouring matter and has wide range of medicinal and pharmacological applications (Chanda et al., 2019). It is used as colouring matter in pharmacy, confectionery, food industry, for dying wool, silk, cotton and in combination with other natural dyes to get different shades. Turmeric is used for the formation of certain cosmetic soaps particularly effective in skin problems and to remove unwanted hairs (Anonymous, 2004). Therapeutically, it has been used for curing in various diseases such as asthma, anemia, chronic bronchitis, chronic dysentery, chronic fever, conjunctivitis, cough, diabetes, diarrhea, dislocation of joint, eye disease, gonorrhea, hepatitis, hysteria, indigestion, itching, leech bite, leprosy, liver disorder, loss of appetite, menstrual disorder, parasitic disease, peptic ulcer, small pox, chicken pox, skin disease, tonsillitis, toothache, urinary infection, urine pain, vaginal discharge, weakness of eye sight etc. (Ahmad et al., 2010). In Ayurveda, it is recommended in elevated condition of Kapha and Pitta. Turmeric is an important component in religious ceremonies and offerings (Dastur, 1970). Turmeric contained an essential oil, an alkaloid, starch grains, yellow matter curcumins and other curcuminoids, turmeric oil, turmerol, coporic acid as free acid, veleric acid as a combined acid (Jain et al., 2007). Several studies showed that turmeric inhibits the growth of several different types of cancer cells. Curcumin can bind with heavy metals such as cadmium and lead there by reducing the toxicity of these heavy metals.

The phytochemical analysis of the methanolic extract of C. longa showed the presence of tannins, alkaloids, saponins, flavonoids, terpenoids, cardiac glycosides, steroids, phytosterol and phenol (Sawant and Godghate, 2013). The photochemical constituents present in ethanol extract of rhizomes of C. longa are alkaloids, saponins, tannins, anthocyanin, emodins, flavonoids, diterpenes, phlobatannin, 
leucoanthocyanin, anthroquinone, chalcones, cardiac glycogides and carbohydrate. The phytochemicalconstituents present in the C. longa have been shown to possess anti-oxidant (Anto et al., 1994), anti-allergic activity, antimicrobial activity (Negi et al., 1999), antibacterial activity (Singh et al., 2002), antiulcer activity, antivenum activity, antifertility and antispermatic activity (Bhagat et al., 2001), antidepresent activity (Xu et al., 2002), antifungal (Lee et al., 2007), antiemetic activity, anti-inflammatory, anticancer, anticarcinogenic, antimutagenic, antifungal, antiviral properties (Chattopadhyay, et al., 2004). Yellow colouring matter curcumins and other curucinoids (diarylheptanoids) and essential oils are the major bioactive ingredients (Sabale et al., 2013). Arutselvi et al., (2012) has reported antimicrobial activity from leaves and rhizomes of C. longa.

Nowadays, the interest in using natural sources or medicinal plants is increasing worldwide due to their safety, efficiency, cultural acceptability and lesser side effect as compared to synthetic drugs. Recent trends in C. longa Linn has been studied by Jain et al. (2007) to review on a description of its various pharmacological actions studied earlier and in the recent times. The objective of the research was phytochemical screening of Curcuma longa for highlighting its traditional uses and pharmacological properties. Phytochemical constituents of Curcuma longa available in Pokhara Metropolitan City-3, Nadipur, Nepal were phytochemically analysed in chemistry research laboratory of Babasab Bhimrao Ambedkar Bihar University, Muzaffarpur, India.

\section{MATERIALS AND METHODS}

\section{Plant material and extract preparation}

Fresh plants of C. longa were collected with leaf and rhizomes from Pokhara metropolitan city-
3, Nadipur, Kaski, Nepal in November 2018. The plant and rhizomes were authenticated by experts. Extraction and phytochemical screening was carried out in Research Laboratory of Department of Chemistry, Babasab Bhimrao Ambedkar Bihar University, Muzaffarpur, India. The rhizomes were washed thoroughly, cut into small pieces, shaded dried completely for a week at room temperature and grounded well into fine powder. The powder was stored in a clean closed air tight container with proper labelling until further use. $40 \mathrm{~g}$ of dried powder of turmeric were placed in the thimble of Soxhlet apparatus. $150 \mathrm{ml}$ of a solvent (methanol or ethanol) was used at a time. The extraction was continued till clear solvent was seen in the thimble. The extract was separated and dried in a digital water bath till a dark orange residue was obtained. The rhizome powder of turmeric was extracted by using a specific solvent separately in an operation. The extracts were kept in a refrigerator at $4^{\circ} \mathrm{C}$ for further use.

\section{Phytochemical Analysis}

The test sample extract was subjected to phytochemical analysis in order to find out the presence or absence of phytochemical constituents. The phytochemical tests were employed for alkaloids, steroids, tannins, saponins, flavonoids, phenols, carbohydrates, cardiac glycosides, phytosterol, anthrocyanin, coumarin, emodins, deterpenes, phlobatannin, locoanthocyanin, anthroquinone, chalcones by adopting standard procedures.

\section{Detection of alkaloids}

Wagner's test: $20 \mathrm{mg}$ of turmeric extract was dissolved in $2 \mathrm{ml}$ of specific solvent with few drops of $1 \% \mathrm{HCl}$ and heated and then cooled. On adding Mayer's reagent (Potassium mercuric iodide) dropwise, the yellow or brown reddish precipitate was indicated that the presence of alkaloids (Ogunlowo et al., 2013). 


\section{Detection of saponins}

Foam test: $40 \mathrm{mg}$ of turmeric extract was mixed with $20 \mathrm{ml}$ of distilled water and shaken vigorously for few minutes. Formation of thick foam layer was indicated that the presence of saponins.

\section{Detection of steroids}

Liebermann-Burchard test: $20 \mathrm{mg}$ of extract was dissolved in $5 \mathrm{ml}$ of solvent (chloroform) containing equal volume of acetic anhydride and few drops of concentrated $\mathrm{H}_{2} \mathrm{SO}_{4}$ was added along the side of test tube. The development of dark green coloration indicated the presence of steroids.

\section{Detection of terpenoids}

Libermann-Burchard test: $20 \mathrm{mg}$ of extract was dissolved in $5 \mathrm{ml}$ of organic solvent (ethanol). To it $5 \mathrm{ml}$ of acetic anhydride was added followed by addition of 1-2 drops of conc. $\mathrm{H}_{2} \mathrm{SO}_{4}$ change of colour from pink to violet/red-violet indicated that presence of terpenoids (Ogunlowo et al., 2013).

\section{Detection of tannins}

$\mathrm{FeCl}_{3}$ Test: $20 \mathrm{mg}$ of extract in $5 \mathrm{ml}$ of solvent (distilled water) was treated with few drops of $1 \% \mathrm{FeCl}_{3}$ solution. Formation of green or blue green colour indicated the presence of tannins.

\section{Detection of phenol}

Ferric chloride test: $20 \mathrm{mg}$ of extract in $5 \mathrm{ml}$ of distilled water was treated with few drops of alcoholic ferric chloride solution and observed for the formation of bluish-black colour (Sawant and Godhate, 2013). This test was similar with the test of tannin.

\section{Detection of flavonoids}

Alkaline reagent test: Extract was treated with $10 \% \mathrm{NaOH}$ solution, formation of intense yellow colour which changes to colourless on adding dilute $\mathrm{HCl}$ was indicated the presence of flavonoids.
Lead acetate test: On adding few drops of lead acetate on few mg of extract, yellow colour precipitate indicated the presence of flavonoids (Evan, 2002).

$\mathrm{Zn}$ test:Formation of red colour on treating $2 \mathrm{ml}$ extract with $\mathrm{Mg}$ or $\mathrm{Zn}$ dust and concentrated $\mathrm{HCl}$ indicated the presence of flavonoids (Shrestha et al. 2016).

\section{Detection of protein}

Biuret's test: A mixture of $2 \mathrm{ml}$ of Biuret reagent and $2 \mathrm{ml}$ of extract was shaken well and warmed in water bath. Apperance of red or violet colour indicated the presence of protein.

\section{Detection of carbohydrates}

Molisch's test: $2 \mathrm{ml}$ of extract was treated with few drops of $\alpha$-naphthol solution. Formation of violet ring at the junction was indicated the presence of carbohydrate

Fehling's test: $2 \mathrm{ml}$ of extract was hydrolysed with $\mathrm{HCl}$, neutralized with $\mathrm{NaOH}$ and heated with Fehling's solution A and B, formation of red precipitate indicated the presence of reducing sugar.

\section{Detection of glycosides}

Keller-killani test:20mg of plant extract was treated with $2 \mathrm{ml}$ glacial acetic acid containing few drops of $\mathrm{FeCl}_{3}$. A brown coloured ring at the junction of two layers on adding 1-2 drops of concentrate $\mathrm{H}_{2} \mathrm{SO}_{4}$ was indicated the presence of glycosides.

\section{Detection of amino acids}

Ninhydrin test:To the two $\mathrm{ml}$ extract, $2 \mathrm{ml}$ of Ninhydrin reagent was added and boil for few minutes. Formation of blue colour was indicated the presence of amino acids.

\section{Detection of anthocyanin}

In the two $\mathrm{ml}$ of aqueous extract, $2 \mathrm{ml}$ of $2 \mathrm{~N} \mathrm{HCl}$ and then $\mathrm{NH}_{3}$ was added. The change of colour from pink-red to blue-violet was indicated the presence of anthocyanin. 


\section{Detection of coumarin}

On adding $3 \mathrm{ml}$ of $10 \% \mathrm{NaOH}$ in $2 \mathrm{ml}$ of the aqueous extract, formation of yellow colour indicated the presence of coumarin in plant extract (Sawant and Godhate, 2013).

\section{Detection of emodins}

$2 \mathrm{ml}$ of $\mathrm{NH}_{4} \mathrm{OH}$ and $3 \mathrm{ml}$ of benzene was added to the extract, apperance of red colourwas indicated the presence of emodins.

\section{Detection of diterpene}

Copper acetate test: Plant extract was dissolved in distilled water and treated with 10 drops of copper acetate solution, the formation of emerald green colour indicated the presence of diterpenes.

\section{Detection of phytosterol}

Salkowski test: $20 \mathrm{mg}$ of extract was dissolved in chloroform which was treated with concentrated sulphuric acid and shaken well and allow standing. Appearance of golden red colour indicated the presence of phytosterol.

\section{Detection anthroquinone}

$5 \mathrm{ml}$ of extract was hydrolysed with dilute sulphuric acid, then $1 \mathrm{ml}$ of benzene and $1 \mathrm{ml}$ of $\mathrm{NH}_{3}$ was added. Formation of rose pink colour indicated the presence of anthroquinone in the plant extract.

\section{Detection of Phlobatannins}

On boiling the aqueous plant extract with $1 \%$ aqueous $\mathrm{HCl}$, deposition of red precipitate indicated the presence of phlobatannins.

\section{Detection of leucoanthocyanin}

On adding $5 \mathrm{ml}$ of isoamyl alcohol into $5 \mathrm{ml}$ of aqueous extract, appearance of red colour upper layer indicated the presence of leucoanthocyanin.

\section{Detection of chalconese}

On adding $2 \mathrm{ml}$ of $\mathrm{NH}_{4} \mathrm{OH}$ to $0.5 \mathrm{gm}$ ethanolic extract, apperance of red colour showed the presence of chalconese

\section{Results and Discussion}

The results of the phytochemical study of methanolic and ethanolic rhizome extract of $C$. longa have been presented in table $\mathbf{1}$

Table 1: Phytochemicals Present in rhizome of Curcuma longa

\begin{tabular}{|c|c|c|c|}
\hline \multirow[t]{2}{*}{ S.No } & & \multicolumn{2}{|c|}{ Extracting Solvents } \\
\hline & & Methanol & Ethanol \\
\hline 1. & Alkaloids & + & + \\
\hline 2. & Steroids & + & + \\
\hline 3. & Tannins & + & + \\
\hline 4. & Saponins & - & - \\
\hline \multirow[t]{2}{*}{5.} & & + & + \\
\hline & $\begin{array}{l}\mathrm{Z} n \\
\text { test }\end{array}$ & - & - \\
\hline 6. & Protein & - & - \\
\hline 7. & Amino acids & - & - \\
\hline 8. & Phenol & + & - \\
\hline \multirow[t]{2}{*}{9.} & & + & + \\
\hline & & + & - \\
\hline 10. & $\begin{array}{l}\text { C a r d i a i c } \\
\text { glycosides: } \\
\text { Keller-Killant } \\
\text { test }\end{array}$ & + & + \\
\hline 11. & Phytosterol & + & + \\
\hline 12 & Anthocyanin & + & + \\
\hline 13 & Coumarin & + & - \\
\hline 14 & Emodins & + & + \\
\hline 15 & Diterpenes & + & + \\
\hline 16 & $\begin{array}{l}\mathrm{L} \text { e u c o } \\
\text { anthocyanin }\end{array}$ & + & + \\
\hline 17 & Anthroquinone & + & + \\
\hline 18 & Chalcones & + & + \\
\hline 19. & Phlobatannin & + & - \\
\hline 20. & Terpenoids & + & + \\
\hline
\end{tabular}


Note: $+=$ present,$-=$ Absent

The phytochemical constituents present in the methanolic extract were more in number than that of ethanolic extract which may due to more extracting capacity of some specific phytochemicals like phenol, phlobatannin etc. In the study, phytochemical constituents alkaloids, steroids, tannins, saponins, flavonoids, phenol, carbohydrates, cardiac glycosides, phytosterol, protein, anthocyanin, coumarin, emodins, diterpenes, amino acids, phlobatannin, leucoanthocyanin, anthroquinone, chalcones, terpenoids were analysed. In the methanolic extract saponin, protein and amino acids, coumarin and phlobatannin were absent. In the ehanolic extract phenol, phlobatannin, protein, amino acids, coumarin and diterpenes were absent. The observed result was almost equivalent with the qualitative phytochemical screening of rhizomes of Curcuma longa linn which has been conducted by Sawant and Godhate (2013). Yellow coloring matter curcumins, other curcuminoids and essential oils were major bioactive ingredients showing various biological activities of turmeric. Some important pharmaceutical properties of turmeric were stated by Sabale et al., (2013). These properties were antiviral (Kim et al. 2001), antifungal (Tushar et al., 2010), anticancer, antidepresent, antimalarial and antimicrobial (Mishra et al. 2009), antiallergic (Tewtrakul et al. 2007), antiseptic (Banerjee and Nigam, 1978), antioxidant (Braga et al., 2003), antiplatelet, (Deodhar et al., 1980), anti-inflammatory (Kohli et al., 2005), Lipid-lowering (Aktar and Taria, 2012) etc.

\section{Conclusions}

Plants are the major source of drugs in the modern as well as traditional system of medicine throughout the world. Curcuma longa has been in used as medicine from the time immemorial to treat wide range of aliments. Curcuma longa is an important medicinal plant that has a number of bioactive compounds. The phytochemical analysis of methanolic extract of $C$. longa showed the presence of some important phytochemicals like alkaloids, steroids, tannins, flavonoids, phenol, carbohydrates, cardiac glycosides, phytosterol, anthrocyanin, coumarin, emodins, deterpenes, phalbatannin, leucoanthocyanin, chalcones, terpenoids. In the ethanolic extract except phenol, phalbatannin, coumarin and deterpenes the other phytochemicals which were observed in methanolic extract were also present. The previous phytochemical study of C. longa showed that it possesses antioxidant, anti-allergic, microbial, antibacterial, antiulcer, antivenum, antiemetic, antidepressant etc. properties. The study encourages the traditional system of medicine and will be applicable for the medicinal plant producer, research institutes, Ayurvedic institution and pharmaceutical companies for the manufacture of new drugs for treatment of various diseases. Further phytochemical analysis of C. longa using solvents of different polarity is essential for highlighting its more phytochemical constituents and medical properties.

\section{ACKNOWLEDGEMENTS}

I would like to express my sincere gratitude to the Head, University Department of Chemistry, Babasab Bhimrao Ambedkar Bihar University, Muzaffarpur, India for providing laboratory facilities and research environment. I would like to offer my gratitude to Prof. Dr. H.C. Rai former Head, University Department of Chemistry, B. R. A. Bihar University, India and Prof. Dr. C. B. Thapa, former Campus Chief, Prithvi Narayan Campus Pokhara, Nepal for providing research guidance, essential advice, valuable suggestions and inspiration during the research work. 


\section{REFERENCES}

Ahmad, W., A. Hasan, A. A. Ansari, and T. Tarannum (2010). Curcuma longa LinnA Review. Happocratic Journal of Unani Medicine. 5 (4): 179-190.

Aktar, N., and M. Tariq (2012). Haqqi. Current nutracenticals in the management of osteoarthritis: A review. Ther Adv Musculoskelet Dis. 4(3): 181-207.

Anonymous (2004). The wealth of India- A Dictionary of Indian Ram Materials and Industrial Products. First Supplement Series, CSIR-NISCAIR, New Delhi. Vol. 2 (Cl-Cy): 264-293.

Anto, R. J., G. Kuttan, K. V. D. Babu, and K. N. Rajesekharan (1994). A comparative study on the pharmacological properties of natural Curcuminoids. Amala Res. Bull.14: 6065.

Arutselvi, R., T. Balasaravanan, P. Ponmurugan, S.N. Muthu, and P. Suresh (2012). Phytochemical screening and comparative study of antimicrobial activity of leaves and rhizomes of turmeric varieties. Asian Journal of Plant Science and Research.2 (2): 212-219.

Banerjee, A. and S. S. Nigam, (1978). Antimicrobial efficacy of essential oil of Curcuma longa Ind. J. Med. Res. 68: 864-866.

Bhagat, M. and A. Purohit (2001). Antifertility effect of various extract of Curcuma longa Linn in male albino rats. Indian Drugs. 38 (2): 78-81.

Braga, M. E., P. F. Leaf, J. E. Carvalho and M. A. Meireles (2003). Comparison of yield, composition and antioxidant activity of turmeric (Curcuma longa L.) extracts obtained using various techniques, J. Agrick Food Chem. 51(22): 6604-6611.

Chanda, S., and T. V. Ramchandra, (2019). Phytochemical and pharmacological importance of turmeric - A Research and
Review: A Journal of Pharmacology.

Chattopadhyay, I., K. Biswas, U. Bandyopadhyay, and R.K. Banerjee (2004). Turmeric and Curcumin: Biological action medical applications. Current Science. 87 (1): 44-50.

Dastur, J. F. (1970). Medicinal plants of India and Pakistan. Bombay: Treasure House of Books.

Deodhar, S. D., R. Sethi, and R. C. Srimal (1980). Preliminary study on antirheumatic activity of curcumin. Indian J Med. Res. 71: 632-634.

Evan, W. C. (2002). Trease and Evans Pharmacognosy $\left(15^{\text {th }}\right.$ ed.). Edinburg: Harcourt Publishers Limited.

Hooker, J. D. (1990). Flora of British India, Connaught Place, Dehradun.Vol 4: 214.

IUCN (2000). National register of medicinal plants. Kathmandu: International Union for Conservation of Nature, Nepal.

IUCN (2011). Selected medicinal plants of Chittagong hill tracts. Dhaka: International Union for Conservation of Nature, Bangladesh Country Office.

Jain, S., S. Shrivastava, S. Nayak, and S. Sumbhate (2007). Recent trends in Curcuma longa Linn. Pharmacognosy Reviews.1 (1): 119-128.

Kim, H. J., H. S. Yoo, J. C. Kim, C. S Park, M. S. Choi, M. Kim, H. Choi, J.S. Min, K.S. Kim, S.W.Yoon, and J. K. Ahn (2001). Antiviral effect of Curcuma longa linn extract against hepatitis B virus replication. J Ethnopharmacol. 124: 457-462.

Kohli, K. and J. Ali (2005). Curcumin: A natural anti-inflammatory agent, Indian, J. Pharmacol. 37: 141-147.

Lee, S. H., K. S. Chang, M. S. Su, Y.S. Hung, H.D. Jang (2007). Effect of some Chinese medicinal plant extracts on five different fungi. Food control. 18: 1547-1554.

Mishra, K., A. P. Das, B. K. Swain, and N. 
Dey (2009). Antimalarial activities of Andrographis panaliculata and hedyotis corymbosa extract and their combination with curcumin. Malar J. 8:26.

Negi, D. S., G. K. Jayprakash, L. M. Rao, and K. K. Sakarian (1999). Antimicrobial action of turmeric oil. J. Agric Food Chem. 47 (10): 297300.

Ogunlowo, O. P, B. D. Arimah, and M. A. Adebayo (2013). Phytochemical analysis and comparison of in-vitro antimicrobial activities of the leaf, stem bark and root bark of Ficus benghalensis. IOSR Journal of Pharmacy.3 (4): 33-38.

Ross, I. A. (2001). Medical Plants of the World, New Jersey, Humana Press. 1: 139-143.

Sabale, P., A. Modi, and V. Sabale (2013). Curcuma longa Linn.: A phytochemical and pharmacological review. Research Journal of Pharmacognosy and Phytochemistry. 5(2): 5968.

Sawant, R. S. and A. G. Godghate (2013). Quantitative phytochemical screening of rhizomes of Curcuma longa Linn. International Journal of Science, Environment and Technology. 2 (1): 634-641.

Shrestha, P., S. Adhikari, B. Lamichhane, and B.G. Shrestha, (2016). Phytochemical screening of medicinal plants of Nepal. IOSR Journal of Environmental Science, Technology and Food Technology (IOSR-JESTFT). 1 (6): 11-17.
Singh, R., R. Chandra, M. Bose, and M Luthra (2002). Antimicrobial activity of C. Curcuma longa rhizome extract on pathogenic bacteria. Curr-Sci. 83(6): 737-742.

Tewtrakul, S. and S. Subhadhirasakul (2007). Anti-allergic activity of some selected plants in the Zingiberaceae family. J Ethnopharmacol. 109 (3): 535-538.

Thomas, F. (2000). PDR for Herbal Medicine, Medicinal Economics Company, Montvale, New Jersey.

Tushar, B. S., G. C. Sarma, and L. Ranjan (2010). Ethno medical uses of Zingiberaceous plants of Northest India. J. Ethnopharmacol. 132 (1): 286-296.

WHO (2002). Legal Status of Traditional Medicine and Complementary/Alternative Medicine: A Worldwide Review. Switzerland, Geneva: World Health Organization.

Xu, Y., B. S. KU, H. Y. Kao, Y. H. Lin, X. Ma, Y. Zhang, and X. Li (2002). The effect of curcumin on depressive like behaviors in mice. Eur J Pharmacol. 518 (1): 40-46. 